\title{
Wetland- An Ecological Boon for the Environment
}

\author{
Wahied Khawar Balwan ${ }^{1 *}$ and Sachdeep Kour ${ }^{2}$ \\ ${ }^{1}$ Assistant Professor, Department of Zoology, Govt. Postgraduate College Bhaderwah, Jammu \& Kashmir, India \\ ${ }^{2}$ Cypress Fairbanks Independent School District Jones Rd, Houston
}

Article History
Received: 22.02 .2021
Accepted: 04.03 .2023
Published: 08.03 .2021
Journal homepage:
http://www.easpublisher.com
Quick Response Code

\begin{abstract}
A wetland is an ecological community that is inundated either year around or seasonally. Wetlands are found from the tundra to the tropics and on every continent except Antarctica. There are many kinds of wetlands and many ways to categorize them. Two general categories of wetlands are recognized namely coastal or tidal wetlands and inland or non-tidal wetlands. Wetlands are among the most productive ecosystems in the world, comparable to rain forests and coral reefs. An immense biodiversity of species of microbes, plants, insects, fish, amphibians, reptiles, birds and mammals can be part of a wetland ecosystem. Wetlands perform significant economic benefits to human society, including some ecosystem services that no other ecosystem can provide, including certain types of water quality improvement, flood protection, shoreline erosion control, and opportunities for recreation and aesthetic appreciation and natural products for our use at no cost. Protecting wetlands in turn can protect our safety and welfare. A primary intent of this article is to provide the reader with special interest in wetland delineation, wetland benefits, wetland mitigation and wetland biology. Wetlands are no more thought to be useless, disease ridden areas rather they are now considered to be an ecological boon for the environment!
\end{abstract}

Keywords: Wetland, Biodiversity, Ecosystem, Coral Reefs, Amphibians, Reptiles, Mammals.

Copyright (C) 2021 The Author(s): This is an open-access article distributed under the terms of the Creative Commons Attribution 4.0 International License (CC BY-NC 4.0) which permits unrestricted use, distribution, and reproduction in any medium for non-commercial use provided the original author and source are credited.

\section{INTRODUCTION}

Wetlands are incredible places with a distinct ecosystem that are flooded with water either permanently or seasonally, and where oxygen-free processes prevail [1]. Wetlands are known by many different names, such as swamps, peat lands, sloughs, swamps, marshes, bogs, mires, fens [2]. The primary feature that distinguishes wetlands from other land forms or water bodies is the characteristic vegetation of aquatic plants known as hydrophytes, adapted to the unique hydric soil [3]. Wetlands were once considered useless, disease ridden places (For Example, Malaria and Yellow fever) to be avoided. However, we now have a better understanding about the importance of wetlands in our environment.

Wetlands provide many societal benefits such as food and habitat for fish and wildlife, including threatened and endangered species, water quality improvement, water storage, flood control, shoreline erosion control, and economically beneficial natural products for human use and opportunities for recreation, aesthetic appreciation, education, and research. There is no doubt that protecting wetlands can, in turn, protect our health and safety by reducing flood damage and preserving water quality. Wetlands are among the most productive and biologically diverse ecosystems in the world, comparable to rain forests and coral reefs. They serve as reservoirs of substantial biodiversity in supporting numerous species from almost all the major groups of organisms from microbes to mammals [4]. The physical and chemical features such as climate, topography (landscape shape), geology, nutrients, and hydrology (the quantity and movement of water) help to determine the plants and animals that inhabit various wetlands. Wetlands in Texas, North Carolina, and Alaska, for example, differ substantially from one another because of their varying physical and biotic nature. Wetlands occur naturally on every continent except Antarctica [5].

The water in wetlands is freshwater, brackish, or saltwater. There are four main types of wetlands namely swamp, marsh, bog, and fen. The sub-types include mangrove forest, carr, pocosin, floodplains, mire, vernal pool, sink, peat lands, bay-gall, etc. Wetlands can be tidal (inundated by tides) or non-tidal. The largest wetlands include the Amazon River basin, the West Siberian Plain, the Pantanal in South America, and the Sundarbans in the Ganges-Brahmaputra delta [6]. 


\section{What is a Wetland?}

A wetland is typically an area of land that is either covered with water or completely saturated with water, whether throughout the year or only during certain seasons. The depth and duration of this seasonal flooding varies. Wetlands are also called as transition zones. They are neither totally dry land nor totally underwater; they have characteristics of both [2]. A wetland's water is often groundwater, seeping up from an aquifer or spring. However, it can also come from a nearby river or lake. Seawater can also create wetlands, especially in coastal areas that experience strong tides. The saturation of wetland soil determines the vegetation that surrounds it. Plants that live in wetlands are uniquely adapted to their watery soil called as hydric soil. Wetland plants are called hydrophytes. Seasonally dry wetlands or wetlands with slow-moving water can often support trees and other sturdy vegetation. More frequently flooded wetlands have mosses or grasses as their dominant hydrophytes [1].

Wetlands exist in many kinds of climates. They vary in size from isolated prairie potholes to huge salt marshes. They are found along coasts and inland. Some wetlands are flooded woodlands, full of trees. Others are more like flat, watery grasslands. Still others are choked by thick, spongy mosses.

\section{Definition of Wetlands}

"Wetland" is a generic term for all the different kinds of wet habitats implying that it is land that is wet for some period, but not necessarily permanently wet. Since wetlands are dynamic systems and occupy the transitional zone between aquatic and terrestrial habitats there is often controversy over dictating boundaries and precise definitions. Wetlands have numerous definitions and classifications as a result of their diversity, the need for their inventory, and the regulation of their uses.

\section{Ramsar Convention Definition}

Ramsar Convention definition is the most widely accepted definition of wetlands. The Ramsar Convention, signed in 1971 in Ramsar, Iran, is the only global treaty that focuses specifically on wetlands. Today 170 nations are signatories to the Ramsar Convention. The Ramsar Convention on Wetlands defines wetlands as "areas of marsh, fen, peat, and or water, whether natural or artificial, permanent or temporary, with water that is static or flowing, fresh, brackish or salt, including areas of marine water the depth of which at low tide does not exceed six meters." The Ramsar definition is one of the broadest definitions of what constitutes a wetland. According to Cowardin and his coworkers, Wetlands include the following main types namely Marine (coastal wetlands such as coastal lagoons, rocky shores, and coral reefs), Estuarine (Deltas, tidal marshes and mangrove swamps), Lacustrine (wetlands associated with lakes), Riverine (wetlands along rivers and streams), Palustrine (marshes, swamps, and bogs) and Human-made wetlands such as reservoirs, fishponds, flooded mineral workings, saltpans, sewage farms and canals [7].

\section{Regional Definitions}

Although the general definition given above applies around the world, each county and region tend to have its own definition for legal purposes. The U. S. Army Corps of Engineers and the Environmental Protection Agency (EPA) in the originally published 1987 Corps of Engineers Wetlands Delineation Manual jointly defined wetlands as: "Those areas that are inundated or saturated by surface or groundwater at a frequency and duration sufficient to support, and that under normal circumstances do support, a prevalence of vegetation typically adapted for life in saturated soil conditions." They continue to describe specifics of the three core components that constitute whether or not an area is a wetland, i.e., Vegetation, Soil, and Hydrology. This definition has been used in the enforcement of the Clean Water Act. Some US states, such as Massachusetts and New York, have separate definitions that may differ from the federal government. The U.S. Fish and Wildlife Service defined wetlands as follows in 1979 as 'Wetlands are lands transitional between terrestrial and aquatic systems where the water table is usually at or near the surface, or the land is covered by shallow water'. Common diagnostic features of wetlands are hydric soils and hydrophytic vegetation. These features will be present except where specific Physico-chemical, biotic, or anthropogenic factors have removed them or prevented their development.

\section{Ramsar Sites in India}

As of December 2020, there are 42 recognized Ramsar sites in India. These are wetlands deemed to be of 'international importance' under the Ramsar Convention. According to WWF (World Wide Fund for Nature) India, wetlands are one of the most threatened of all ecosystems in India. Loss of vegetation, salinization, excessive inundation, water pollution, invasive species, excessive development and road building, have all damaged the country's wetlands.

\section{Characteristics of Wetland}

Wetlands must have one or more of the following three attributes namely:

1. At least periodically, the land supports predominantly hydrophytes

2. The substrate is predominantly undrained hydric soil and

3. The substrate is saturated with water or covered by shallow water at some time during the growing season of each year.

'Hydric soil' means soil that, in its undrained condition, is saturated, flooded, or ponded long enough during a growing season to develop an anaerobic condition that supports the growth and regeneration of hydrophytic vegetation. Hydrophytic vegetation is a 
plant growing in water or a substrate that is at least periodically deficient in oxygen during a growing season as a result of excessive water content.

Water saturation (hydrology) largely determines how the soil develops and the types of plant and animal communities living in and on the soil. Wetlands may support both aquatic and terrestrial species. The prolonged presence of water creates conditions that favor the growth of specially adapted plants (hydrophytes) and promote the development of characteristic wetland soils. When the upper part of the soil is saturated with water at growing season temperatures, soil organisms consume the oxygen in the soil and cause conditions unsuitable for most plants. Such conditions also cause the development of soil characteristics (such as color and texture) of so called hydric soils. The plants that can grow in such conditions, such as marsh grasses, are called hydrophytes. Together, hydric soils and hydrophytes give clues that a wetland area is present. The most important characteristics of wetlands are hydric soils and hydrophytic vegetation. The presence of water by ponding, flooding or soil saturation is not always a good indicator of wetlands. Except for wetlands flooded by ocean tides, the amount of water present in wetlands fluctuates as a result of rainfall patterns, snow melt, dry seasons and longer droughts. Some of the most wellknown wetlands, such as the Everglades and Mississippi bottom land hardwood swamps, are often dry. In contrast, many upland areas are very wet during and shortly after wet weather.

\section{Ecological Roles of Wetlands}

Wetlands are among the most productive ecosystems in the world, comparable to rain forests and coral reefs. An immense biodiversity of species of microbes, plants, insects, amphibians, reptiles, birds, fish, and mammals can be part of a wetland ecosystem. Physical and chemical features such as climate, topography, geology, and the movement and abundance of water determine the plants and animals that inhabit each wetland. The complex, dynamic relationships among the organisms inhabiting the wetland environment are referred to as food chains. Wetlands can be thought of as biological supermarkets. They provide great volumes of food that attract many animal species. These animals use wetlands for part of or all of their life cycle. Dead plant leaves and stems break down in the water to form small particles of organic material called detritus. This enriched material feeds many aquatic insects, shellfish, and small fish that are food for larger predatory fish, reptiles, amphibians, birds and mammals. The functions of a wetland and the values of these functions to human society depend on a complex set of relationships between the wetland and the other ecosystems in the watershed. A watershed is a geographic area in which water, sediments, and dissolved materials drain from higher elevations to a common low-lying outlet or basin a point on a larger stream, lake, underlying aquifer, or estuary [8]. Wetlands play an integral role in the ecology of the watershed. The combination of shallow water, high levels of nutrients, and primary productivity is ideal for the development of organisms that form the base of the food web and feed many species of fish, amphibians, shellfish, and insects. Many species of birds and mammals rely on wetlands for food, water, and shelter, especially during migration and breeding. Wetland microbes, plants, and wildlife are part of global cycles for water, nitrogen, and sulfur. Furthermore, scientists are beginning to realize that atmospheric maintenance may be an additional wetlands function. Wetlands store carbon within their plant communities and soil instead of releasing it to the atmosphere as carbon dioxide or methane. Thus, wetlands help to moderate global climate conditions, and may provide an important regulating influence to deter climate alteration [9].

\section{Classification of Wetlands}

Wetlands are found from the tundra to the tropics and on every continent except Antarctica. Wetlands vary widely because of regional and local differences in soils, topography, climate, hydrology, water chemistry, vegetation and other factors, including human disturbance. There are many kinds of wetlands and many ways to categorize them. NOAA classifies wetlands into five general types namely marine (ocean), estuarine (estuary), riverine (river), lacustrine (lake), and palustrine (marsh).

Common names for wetlands include marshes, estuaries, mangroves, mudflats, mires, ponds, fens, swamps, deltas, coral reefs, billabongs, lagoons, shallow seas, bogs, lakes, and flood plains, to name just a few!

\section{Categories of Wetlands}

The wetlands are generally categorized into following two categories:

1) Coastal/Tidal Wetlands: Coastal/tidal wetlands in the United States, as their name suggests, are found along the Atlantic, Pacific, Alaskan and Gulf coasts. They are closely linked to our nation's estuaries where sea water mixes with fresh water to form an environment of varying salinities. The salt water and the fluctuating water levels (due to tidal action) combine to create a rather difficult environment for most plants. Consequently, many shallow coastal areas are unvegetated mud flats or sand flats. Some plants, however, have successfully adapted to this environment. Certain grasses and grass-like plants that adapt to the saline conditions form the tidal salt marshes that are found along the Atlantic, Gulf, and Pacific coasts. Mangrove swamps, with salt-loving shrubs or trees, are common in tropical climates, such as in southern Florida and Puerto Rico. Some tidal freshwater wetlands form beyond the upper edges 
of tidal salt marshes where the influence of saltwater ends.

2) Inland/Non-tidal Wetlands: Inland/non-tidal wetlands are most common on floodplains along rivers and streams (riparian wetlands), in isolated depressions surrounded by dry land (for example, playas, basins and potholes), along the margins of lakes and ponds, and in other low-lying areas where the groundwater intercepts the soil surface or where precipitation sufficiently saturates the soil (vernal pools and bogs). Inland wetlands include marshes and wet meadows dominated by herbaceous plants, swamps dominated by shrubs, and wooded swamps dominated by trees. Certain types of inland wetlands are common to specific regions of the country. Many of these wetlands are seasonal (they are dry one or more seasons every year), and, particularly in the arid and semiarid West, may be wet only periodically. The quantity of water present and the timing of its presence in part determine the functions of a wetland and its role in the environment. Even wetlands that appear dry at times for significant parts of the year, such as vernal pools, often provide critical habitat for wildlife adapted to breeding exclusively in these areas.

\section{Types of Wetlands}

There are many different types of wetlands, each determined by its hydrology, water chemistry, soils, and the plant species found there. Wetlands may be characterized as dominated by trees, shrubs, or herbaceous vegetation. They may be fed by precipitation, runoff, or groundwater, with water chemistry ranging from very acidic to alkaline. There are four major wetland types found around the globe. They are swamps, marshes, bogs, and fens [1].

1. Marshes: Marshes are nutrient-rich wetlands that are periodically inundated by standing or slowly moving water. Marshes can be freshwater or saltwater and amount of water in the marsh can change with the seasons. They boast a great variety of vegetation that has adapted to live in saturated soil. Vegetation includes cattails, reeds, rushes and sedges. Marshes wildlife includes beavers, alligators, newts, shrimp and turtles. There are several sub-categories of marsh, including freshwater, saltwater, inland and coastal. Each of these have their own distinct ecosystems and can be found all over the world. Marshes are often divided into freshwater and saltwater categories.

a) Freshwater Marshes: Freshwater marshes, often found hundreds of kilometers from the coast, are dominated by grasses and aquatic plants. These marshes often develop around lakes and streams. Many freshwater marshes lie in the prairie pothole region of North America, the heart of which extends from central Canada through the northern Midwest of the United States. Prairie potholes are bowl-shaped depressions left by chunks of glacial ice buried in the soil during the most recent ice age. When the ice melted, muddy water filled the potholes. Fertile soil and a temperate climate make these marshes some of the richest in the world. Thousands of migratory birds depend on the remaining prairie potholes as they travel from the Arctic to more temperate climates every year.

b) Saltwater Marshes: Salt marshes are some of the richest ecosystems for biodiversity. Dominated by grasses, they provide food and shelter for algae, fungi, shellfish, fish, amphibians, and reptiles. Wading birds and other animals feed on the vegetation and abundant insects. The warm saltwater marshes of northern Australia are influenced by the tides of the Indian and Pacific oceans. They often overlap with the freshwater marshes of rivers, such as the Jardine. A few mangrove trees may dot saltwater marshes, but they are dominated by grasses and a layer of algae called an algal mat. This algal mat is home to many insects and amphibians.

2. Swamps: A swamp is a wetland permanently saturated with water and dominated by trees. There are two main types of swamps: freshwater swamps and saltwater swamps. Freshwater swamps are common in inland areas. Saltwater swamps protect coasts from the open ocean.

a. Freshwater Swamps: Freshwater swamps often form on flat land around lakes or streams, where the water table is high, and runoff is slow. Seasonal flooding and rainwater cause the water level in these swamps to fluctuate, or change. Watertolerant plants, such as cattails, lotus, and cypress, grow in the swamp's wet soil. These plants are key to maintaining the swamp's ecosystem. Freshwater swamps are common in tropical areas near the Equator. These equatorial swamps usually experience year-round heat and humidity. The Eastern and Western Congolian Swamp Forests surround the Congo River, 
in the nations of the Democratic Republic of Congo and the Republic of the Congo. Tall evergreen trees dominate the swamp forests. Many species of these trees, such as bubinga and ovangkol, are harvested for timber. The muddy floor of these swamps is home to hundreds of insects, reptiles, and amphibians, including dozens of species of frogs.

a. Saltwater Swamps: Saltwater swamps are usually found along tropical coastlines. Formation of these swamps begins with bare flats of mud or sand that are thinly covered by seawater during high tides. The brackish water of saltwater swamps is not entirely seawater, but not entirely freshwater, either. Some hydrophytes, such as mangrove trees, can tolerate brackish water. Mangroves are easy to recognize because of their tall, stilt-like roots, which hold the small trunks and branches of the trees above water. Mangrove roots anchor sediment and help soil accumulate around them. They also help build sediment through their growth and decay. Many organisms live among mangrove roots. The root system provides shelter and a place to feed on fallen leaves and other material. Crabs, conchs, and other shellfish are abundant in mangrove swamps. Saltwater swamps are also home to a huge variety of birds. Mangrove roots and branches provide excellent nesting sites. Saltwater swamps are home to seabirds, such as gulls, as well as freshwater birds, such as herons. The abundance of plants, insects, and small animals provides food for these birds, whose droppings help fertilize the swamp. The Sunderbans, a saltwater swamp in India and Bangladesh, has the largest mangrove forest in the world (Frazer et al., 2005). Located on mud flats near the delta of the Ganges River, the area is saturated in freshwater. The Sundarbans also experience strong tides from the Indian Ocean.

The biodiversity of the Sundarbans stretches from tiny algae and moss to Bengal tigers. The Bangladeshi portion of the wetland is a UNESCO World Heritage Site. Dozens, perhaps hundreds, of different species of mangrove trees thrive in the Sundarbans. In drier areas of the swamp, palms and grasses grow. Insects such as bees build hives in the trees. In fact, harvesting honey has been a major economic activity in the Sundarbans for centuries. Bees and other insects are one of the main food sources for tropical birds in the area. Storks, ibises, and herons' nest in the high branches of mangrove and palm trees. Smaller birds such as kingfishers and pigeons roost in shrubs. Some birds feed on the hundreds of fish that inhabit the Sundarbans' brackish water: rays, carp, eels, crabs, and shrimp. Many reptiles and amphibians live in and around the swamp, including frogs, toads, turtles, and snakes. Some of the snakes of the Sundarbans, such as the Indian python, regularly grow up to 3 meters (10 feet) long. Monitor lizards and crocodiles, also native to the Sundarbans, are even larger.

The large reptiles of the Sundarbans regularly prey on mammals such as deer, boar, mongooses, and monkeys. However, the most famous predator of the Sundarbans is the Bengal tiger, an endangered species. Bengal tigers are apex predators - human beings are their only natural predator. In the Sundarbans, Bengal tigers swim in the swampy water and climb trees. The cats, which can grow to 220 kilograms (484 pounds), have been known to attack people in the swamp. Scientists and honey collectors are especially at risk.

Swamps differ from marshes in that, typically, they are dominated by woody plants (rather than soft-stemmed plants). Some of these trees are often harvested by people from all over the world to make timber and to build their homes, which can affect the ecosystem drastically if too many are taken without being replaced with new saplings.

3. Bogs: Bogs are characterized by more acidic waters and spongy peat deposits as well as a covering of sphagnum moss. Unlike marshes and swamps, bogs tend to get their wetness from precipitation rather than waterways such as streams or runoffs from rivers. These wetlands are fantastic for preventing downstream flooding since they absorb precipitation as it falls and prevents the swelling of rivers and other waterways. There are two sorts of bogs namely northern bogs and pocosins. Swamps and marshes are generally found in warm climates. Bogs are more common in cold or even Arctic areas in North America, Europe, and Asia. They also exist at high altitudes in warmer regions, such as the Sierra Nevada in the United States. Bogs are often called moors or fens in Europe, and muskegs in Canada. Like many wetlands, bogs 
develop in areas where the water table, or the upper surface of underground water, is high. They often begin in glacial depressions called kettle lakes, which are deeper than prairie potholes. A bog forms as a kettle lake gradually fills with plant debris. Leaves, roots, and stems of large plants accumulate on the bed of the lake. As the lake becomes shallower, mosses and other plants growing along the edges of the lake extend into the water. They form a loose, floating layer of tangled vegetation on the water's surface. Eventually, these plants are followed by waterloving grasses and sedges. Soon, the water is choked with vegetation. The oldest, partially decayed vegetation at the bottom of the bog forms a thick, spongy mat called peat. Peat is a valuable fuel in many parts of the world. It is often the first step in the creation of coal, a fossil fuel. (The fossils in coal are wetland plants.) Some people living near bogs cut and dry squares of peat. It is burned for heating and cooking or used to insulate buildings. In Ireland, peat supplies a portion of the country's electrical energy.

4. Bogs preserve more than the remains of plants, however. The bodies of dozens of prehistoric people have been found in bogs in Europe and Asia. These bog bodies have been preserved for thousands of years. Bog bodies are in such excellent condition that anthropologists can examine clothes, tattoos, and hair color, and even investigate a cause of death. Most people found in bogs were killed, though historians and anthropologists' debate whether they were murdered or sacrificed as part of a religious ritual.

Some bogs can support a person's weight. They are called quaking bogs because the surface quakes when a person walks on the spongy peat. The island of Ireland, with its cool, wet climate, has hundreds of quaking bogs. Unlike other wetlands, bogs usually are not agriculturally fertile. The amount of acid in the soil and water is generally higher than that in swamps or marshes. The supply of nutrients, especially nitrogen, is low. Only certain kinds of plants can grow in bogs. Some of the few plants harvested in the wet, acidic soil of bogs are cranberries and blueberries. Plants are autotrophs, able to make their own food from air, water, and sunlight. Many bog plants have adapted to the poor nutrients in the soil and water by expanding their food source. Pitcher plants and sundew, common in bogs, are carnivorous. They trap and consume insects. Because of the limited species of plants, bogs do not have the biodiversity common in other types of wetlands. Insects, common in all wetlands, include butterflies and dragonflies. These insects feed on the nectar in bog flowers. Ireland has dozens of native butterflies found in bogs. Birds, such as geese and pheasant, also make their homes in the bog, although it is unusual to find larger animals. In North America, moose are one of the few large animals that thrive in bog habitats. Moose, the largest species of deer, consume aquatic plants such as pond lilies.

5. Fens: Fens are, like bogs, peat-forming wetlands, although they usually get their wetness from ground water rather than precipitation, which means that they are slightly less acidic. This means that they tend to support a greater array of wildlife, from plants to fish to birds and everything in between. Like bogs, fens are beneficial because they can help prevent the flooding of land elsewhere, since they soak up water from the ground and prevent it from seeping anywhere else.

\section{Wetlands and Climate Change}

Wetlands perform two important functions in relation to climate change. They have mitigation effects through their ability to sink carbon, converting a greenhouse gas (carbon dioxide) to solid plant material through the process of photosynthesis, and also through their ability to store and regulate water. Wetlands store approximately 44.6 million tonnes of carbon per year globally [10]. Coastal wetlands, such as tropical mangroves and some temperate salt marshes, are known to be sinks for carbon that otherwise contributes to climate change in its gaseous forms (carbon dioxide and methane). The ability of many tidal wetlands to store carbon and minimize methane flux from tidal sediments has led to sponsorship of blue carbon initiatives that are intended to enhance those processes. However, depending on their characteristics, some wetlands are a significant source of methane emissions and some are also emitters of nitrous oxide, which is a greenhouse gas with a global warming potential 300 times that of carbon dioxide and is the dominant ozone-depleting substance emitted in the $21 \mathrm{st}$ century. Excess nutrients mainly from anthropogenic sources have been shown to significantly increase the $\mathrm{N}_{2} \mathrm{O}$ fluxes from wetland soils through denitrification and nitrification processes [10].

A study in the intertidal region of a New England salt marsh showed that excess levels of nutrients might increase $\mathrm{N}_{2} \mathrm{O}$ emissions rather than sequester them [15]. Aquatic invertebrates produce ecologically relevant nitrous oxide emissions due to ingestion of denitrifying bacteria that live within the subtidal sediment and water column and thus may also 
be influencing nitrous oxide production within some wetlands.

\section{Benefits of Wetlands}

In the not too distant past, wetlands were regarded as wastelands. Most people felt that they were places to be avoided, and it was common practice to drain them, fill them or treat them as dumping grounds. A study published by the U.S. Fish and Wildlife Service in 1990 revealed a startling fact: more than half of the 221 million acres of wetlands that existed in the lower 48 states of USA have been destroyed in the late 1700s. Today, we know that wetlands are most biologically productive ecosystems in the world that provide numerous benefits to the environment and to the society. They offer critical wildlife habitat, prevent shoreline erosion, purify polluted waters, etc. They also provide a wide variety of recreational opportunities such as fishing, hunting, photography, and wildlife observation. As several wetland functions and values have become more widely known, wetlands are increasingly seen as productive and valuable resources worthy of protection and restoration. These benefits become increasingly significant as we continue to lose wetlands around the globe.

Since there are several different types of wetlands, there are many benefits that each one offers. Not all of them offer the same benefits to animal or plant life, but all of them are essential and it is very important to protect both them and the life that they support. Following are some of the benefits of wetlands:

1) Water Quality and Hydrology: Wetlands have important filtering capabilities for intercepting surface water runoff from higher dry land before the runoff reaches open water. As the runoff water passes through, the wetlands retain excess nutrients, remove pollutants, and reduce sediment that would clog waterways and affect fish and amphibian egg development [5]. In performing this filtering function, wetlands save a great deal of money. For example, a 1990 study showed that without the Congaree Bottomland Hardwood Swamp in South Carolina, the area would need a US \$5 Million wastewater treatment plant. In addition to improving water quality through filtering, some wetlands maintain stream flow during dry periods, and many replenish groundwater. Many Americans depend on groundwater for drinking. Wetlands can positively impact water supply, serving as reservoirs for the watershed and releasing retained water into surface water and ground water [11]. Thus, wetlands are one of the most productive and critical natural filtering systems in the world [11].
2) Flood Protection: Wetlands can play an important role in flood abatement, soaking up and storing floodwater. According to the EPA (Environmental Protection Agency), U.S. flood damages average $\$ 2$ billion annually. A wetland can typically store 3-acre feet of water, the equivalent of 1 million dollars. Wetlands function as natural sponges that trap and slowly release surface water, rain, snowmelt, groundwater and flood waters. Trees, root mats, and other wetland vegetation also slow the speed of flood waters and distribute them more slowly over a floodplain. This combined water storage and braking action lowers flood heights and reduces erosion. Wetlands within and downstream of urban areas are particularly valuable, counteracting the greatly increased rate and volume of surface water runoff from pavement and buildings. The holding capacity of wetlands helps control floods and prevents water-logging of crops. Preserving and restoring wetlands, together with other water retention, can often provide the level of flood control otherwise provided by expensive dredge operations and levees. The bottomland hardwood-riparian wetlands along the Mississippi River once stored at least 60 days of floodwater. Now they store only 12 days of such high flow, because most have been filled or drained. Wetland has a positive impact not only on the environment but is also very useful for people who have built their settlements next to rivers or other waterways that might otherwise have been prone to flooding.

3) Shoreline Erosion: The ability of wetlands to control erosion is so valuable that some states are restoring wetlands in coastal areas to buffer the storm surges from hurricanes and tropical storms. Wetlands at the margins of lakes, rivers, bays, and the ocean protect shorelines and stream banks against erosion. Wetland plants hold the soil in place with their roots, absorb the energy of waves, and break up the flow of stream or river currents. Emergent, plants that are firmly rooted in the ground but that have stalks that rise out of the water into the air, grow almost exclusively in wetlands, and it is this that slows the flow of water. This means that the strength of the water is lessened, and erosion occurs less powerfully in these sorts of areas, as well as in lakes and rivers where the water is slower. Thus, Wetlands act as a sort of erosion control.

4) Wildlife Nursery: Wetlands serve as homes to many plant and animal species, including threatened \& endangered species. Wetlands provide shelter for all sorts of different species 
of animals. Because the wetlands have salt water, fresh water, trees, and land, they provide shelter and food for all sorts of wildlife. Wetland birds include ducks, geese, kingfishers, ibises, and sandpipers. Plus, wetlands provide a pit stop for migratory birds. Mammals like otters, waterbucks and beavers live in wetlands. And of course, there are also a large variety of fish and alligators and snakes. They offer the perfect place for animals to be safe and hidden from predators as well as providing a great deal of diverse foodstuffs such as grasses, mosses and other plant life. Amphibians may hunt and scavenge away from the wetlands, but they always return to find a good place to mate and breed, because wetlands offer a lot more safety than other places.

5) Habitat Enhancement: Wetlands can enhance habitat for game and non-game species. According to EPA (Environmental Protection Agency), wetlands provide an essential link in the life cycle of 75 percent of the fish and shellfish commercially harvested in the U.S., and up to 90 percent of the recreational fish catch. U.S. consumers spent an estimated $\$ 54.4$ billion for fishery products in 2000 . According to EPA, wetlands also provide habitat for threatened and endangered species. Wetlands make up an estimated 5 percent of the land area of the lower 48 US states, yet more than one-third of threatened and endangered species live only in wetlands. An additional 20 percent of the country's threatened and endangered species use or inhabit wetlands at some time in their life. Without wetlands, a huge number of songbirds, waterfowl, shellfish, and mammals just wouldn't exist.

6) Pollution Filter \& Climate Controller: If trees are the lungs of the planet, then wetlands are its kidneys. Wetlands play a significant role to filter pollution. They help to clean drinking water. Wetlands trap pollutants like heavy metals in their soil and break them; they also break down suspended solids to neutralize harmful bacteria. Wetlands also capture carbon and bury it away in the water and sediments in wetlands (On the Rouge River near Detroit, Michigan, a wetland demonstration project showed significant reductions in nitrates, phosphorus, and heavy metals. Clean and plentiful drinking water depends on healthy wetlands. Wetlands, and in particular marshes, play a major role in treating and detoxifying a variety of waste products. Some wetlands have been found to reduce the concentration of nitrate by more than $80 \%$ [12]. Without wetlands, coastal cities can be in danger of disappearing from a hurricane or flooding. Moreover, animals may become endangered or disappear forever without the wetland habitats.

7) Release Vegetative Matter: Wetlands release water back into waterways and surrounding areas, although they do so slowly, which is why they are so good at preventing flooding. This water, after having been in areas that are so rich in various sorts of plant life, is filled with vegetative matter that then finds its way into rivers and streams. This vegetative matter is essential for sustaining the fish that live in these waterways as well as can help to stabilize, rejuvenate or enrich ecosystems in areas around wetlands.

8) Storm Buffer: Scientists have estimated that every three miles of healthy wetlands could trim about one foot off a storm surge. For places like Louisiana, which have undergone tremendous erosion from oil and gas development and manmade levees, restoring and conserving wetlands is critical. In fact, wetlands provide $\$ 23.2$ billion per year in storm protection services alone. In Louisiana, the wetlands are essential to help protect the state from hurricanes. The wetlands are essential to protect all of the coastal communities and even New Orleans.

9) Wind Buffer: The trees and the land help to buffer wind. This helps to reduce the impact of waves and water swells during storms and hurricanes. A study co-authored by Earth Share member The Nature Conservancy showed that mangrove forests, which grow in wetlands and coastal areas, can reduce wind and swell waves, significantly; almost $100 \%$, in fact, with 500 meters of forest!

10) Carbon Sink: The soils found in wetlands can store carbon for hundreds of years, they play an important role in fighting climate change [9].

11) Recreation and Aesthetics: Wetlands provide people with many ways to enjoy nature. It is a destination for outdoor activities such as biking, hiking, kayaking, fishing, bird watching, photography, boating, and hunting. Wetlands have recreational, historical, scientific, and cultural value. More than half of all U.S. adults (98 million) hunt, fish, bird watch or photograph wildlife. They spend a total of US $\$ 59.5$ billion annually on activities that are pursued in wetlands and other natural areas. Painters and writers capture the beauty 
of wetlands on canvas and paper, or through cameras, and video and sound recorders. Others appreciate these wonderlands through hiking, boating, and other recreational activities. Almost everyone likes being near the water; part of the enjoyment is the varied, fascinating life forms. Because the wetlands are great habitats, people can enjoy learning more about the animals in them and protect the animals in their own habitat.

12) Natural Products of Economic value: We use a wealth of natural products from wetlands, including fish and shellfish, blueberries, cranberries, timber, and wild rice, as well as medicines that are derived from wetland soils and plants. Many of the nation's fishing and shell fishing industries harvest wetland-dependent species; the catch is valued at US\$15 billion a year. In the Southeast, for example, nearly all the commercial catch and over half of the recreational harvest are fish and shellfish that depend on the estuary-coastal wetland system. Louisiana's coastal marshes produce an annual commercial fish and shellfish harvest that amounted to 1.2 billion pounds worth US\$244 million in 1991. Wetlands are habitats for fur-bearers like muskrat, beaver, and mink as well as reptiles such as alligators. The nation's harvest of muskrat pelts alone is worth over US\$70 million annually.

13) Education: Wetlands protection activities provide meaningful opportunities to educate the public regarding wetlands science, wetlands protection, and the value of water resources.

14) Fertile Farmland: Wetlands throughout the world are used as farms because of the rich nutrients that are in the ground. The staple diet of half the world's population is rice, which grows in wetlands in many parts of the world. Many commercially important fish species, reeds and papyrus are also harvested in wetlands.

15) Jobs Hub: US coastal regions provide $40 \%$ of the country's employment: more than 69 million jobs in sectors like trade, hospitality, and commercial fishing. Restoring wetlands also provides many jobs. A study from the Center for American Progress found that for every \$1 million invested in coastal restoration, 17.1 jobs were created.

16) Sea Level Rise Mitigation: By 2100, New York City could witness sea level rise of up to six feet. For those living within this rapidly expanding flood zone, wetlands will provide a critical buffer. That's why the city is supporting programs like Marshes, a 68 acre wetland mitigation bank on Staten Island.

\section{Human impacts on wetlands}

Human activities cause wetland degradation and loss by changing water quality, quantity, and flow rates; increasing pollutant inputs; and changing species composition as a result of disturbance and the introduction of nonnative species.

\section{Hydrologic Alterations}

A wetland's characteristics evolve when hydrologic conditions cause the water table to saturate or inundate the soil for a certain amount of time each year. Any change in hydrology can.

Significantly alter the soil chemistry and plant and animal communities. Common hydrologic alterations in wetland areas include:

- Deposition of fill material for development

- Drainage for development, farming, and mosquito control

- Dredging and stream channelization for navigation, development, and flood control

- Diking and damming to form ponds and lakes

- Diversion of flow to or from wetlands and

- Addition of impervious surfaces in the watershed, thereby increasing water and pollutant runoff into wetlands.

\section{Pollution Inputs}

Although wetlands are capable of absorbing pollutants from the surface water, there is a limit to their capacity to do so. The primary pollutants causing wetland degradation are sediment, fertilizer, human sewage, animal waste, road salts, pesticides, heavy metals, and selenium. Pollutants can originate from many sources, including:

- Runoff from urban, agricultural, silvicultural, and mining areas

- Air pollution from cars, factories, and power plants

- Old landfills and dumps that leak toxic substances and

- Marinas, where boats increase turbidity and release pollutants.

\section{Vegetation Damage}

Wetland plants are susceptible to degradation if subjected to hydrological changes and pollution inputs. Other activities that can impair wetland vegetation include:

- Grazing by domestic animals;

- Introduction of nonnative plants that compete with natives; and

- Removal of vegetation for peat mining. 


\section{World wetlands day}

World Wetlands Day is celebrated on the 2nd day of February every year, marking the date of the adoption of the Ramsar convention on 2 February 1971. Established to raise awareness about the value of wetlands for humanity and the planet, WWD was celebrated for the first time in 1997, and has grown remarkably since then. In 2015 World Wetlands Day was celebrated in 59 countries. WWD serves to recognize the influence and positive production that wetlands have had on the world and in terms brings communities together for the benefit of Mother Nature. This day also raises global awareness because wetlands play a significant role not only for humans, but for all sorts of organisms in this world. Over time, human construction has led to various ecological problems affecting wetlands. Over-population and construction have led to a decrease in environmental conservation and in total has brought upon issues to these marvelous lands. Many wetlands are being lost and we must recognize this dilemma before we lose a natural filter and conserver of the world [13]. Wetlands were once thought of as useless swamps. But now, we know they are home to abundant fish and wildlife. Whenever you investigate a water body and see a small environment of plant life and organisms, think of a wetland is in observation. We as a world community should protect these amazing communities of life and gift of nature, our wetlands.

\section{Wetland conservation, restoration, and protection}

Wetlands have historically been the victim of large draining efforts for real estate development, or flooding for use as recreational lakes or hydropower generation. Some of the world's most important agricultural areas are wetlands that have been converted to farmland. Since the 1970s, more focus has been put on preserving wetlands for their natural function yet by 1993 half the world's wetlands had been drained. In order to maintain wetlands and sustain their functions, alterations and disturbances that are outside the normal range of variation should be minimized.

Wetland restoration is the manipulation of a former or degraded wetland's physical, chemical, or biological characteristics to return its natural functions. Restoration practices include Re-establishment, the rebuilding a former wetland and Rehabilitation, repairing the functions of a degraded wetland [14].

Wetlands protection is defined as removing a threat or preventing the decline of wetland conditions [14]. In addition to restoring compromised wetlands, voluntary protection of naturally occurring wetlands is a valuable part of voluntary wetland restoration and protection.

Artificial wetlands do not have hydric soil. The soil has very low levels of organic carbon and total nitrogen compared to natural wetland systems, and this reduces the performance of several functions. Constructed wetlands can take 10-100 years to fully resemble the vegetative composition of a natural wetland.

\section{CONCLUSION}

In this article, we have tried to highlight the incalculable value of wetlands for our environment, and the threat that climate change and human interference poses to them. We now realize that many of our wetlands have been destroyed or degraded due to development, misguided engineering projects, agriculture, and fossil fuel development. We are just beginning to understand the vital services that wetlands provide and are designing the blueprint for restoring these precious gifts of Mother Nature, the Wetlands!

\section{REFERENCES}

1. Keddy, P. A. (2010). Wetland ecology: principles and conservation. Cambridge university press.

2. Mitsch, W.J., \& Gosselink, J.G. (2007). Wetlands (4th ed.). New York, NY: John Wiley \& Sons.

3. Butler, S. (2010). Macquarie Concise Dictionary (5th ed.). Sydney, Australia: Macquarie Dictionary Publishers.

4. Dorney, J., Savage, R., Adamus, P., \& Tiner, R. (2018). Wetland and Stream Rapid Assessments: Development, Validation, and Application. London; San Diego, CA: Academic Press.

5. Davidson, N.C. (2014). How much wetland has the world lost? Long-term and recent trends in global wetland area.Marine and Freshwater Research, 65(10): 934-941.

6. Giri, C., Pengra, B., Zhu, Z., Singh, A., \& Tieszen, L.L. (2007). Monitoring mangrove forest dynamics of the Sundarbans in Bangladesh and India using multi-temporal satellite data from 1973 to 2000. Estuarine, Coastal and Shelf Science, 73(12): 91-100.

7. Cowardin, L.M., Carter, V., Golet, F.C., \& LaRoe, E.T. (1979). Classification of wetlands and deep water habitats of the United States: U.S. Fish and Wildlife Service Report FWS/OBS-79/31, 131.

8. Richardson, J. L., Arndt, J.L., \& Montgomery, J. A. (2001). Hydrology of wetland and related soils. In Richardson, J.L., Vepraskas, M. J. (eds.). Wetland Soils. Boca Raton, FL: Lewis Publishers.

9. Ponnamperuma, F. N. (1972). The chemistry of submerged soils. Advances in Agronomy, 24, 2996.

10. Moseman-Valtierra, S. (2012). Reconsidering the climatic roles of marshes: Are they sinks or sources of greenhouse gases?". In Abreu, D. C.; Borbón, S. L. (eds.). Marshes: Ecology, Management and Conservation. New York, NY: Nova Science.

11. Maltby, E. (1986). Waterlogged Wealth: Why waste the world's wet places? Earth scan. London: 
International Institute for Environment and Development.

12. Davidson, N.C., D'Cruz, R., \& Finlayson C.M. (2005). Ecosystems and Human Well-being: Wetlands and Water Synthesis: a report of the Millennium Ecosystem Assessment. Washington, DC: World Resources Institute.

13. Silliman, B.R., Grosholz, E.D., \& Bertness, M.D. (2009). Human Impacts on Salt Marshes: A Global Perspective. Berkeley, CA: University of California Press.
14. US EPA, O.W. (2007). Basic information about wetland restoration and protection. US EPA. Retrieved, 2021-02-20.

15. Fraser, L., Keddy, P.A., eds. (2005). The World's Largest Wetlands: Their Ecology and Conservation. Cambridge, UK: Cambridge University Press.

16. Martin, R.M., Wigand, C., Elmstrom, E., Lloret, J., \& Valiela, I. (2018). Long-term nutrient addition increases respiration and nitrous oxide emissions in a New England salt marsh. Ecology and Evolution, 8(10): 4958-4966.

Cite This Article: Wahied Khawar Balwan \& Sachdeep Kour (2021). Wetland - An Ecological Boon for the Environment. East African Scholars J Agri Life Sci, 4(3), 38-48. 